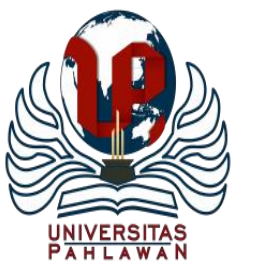

Jurnal Basicedu Volume 4 Nomor 4 Tahun 2020 Halm. 801 - 812

JURNAL BASICEDU

Research \& Learning in Elementary Education

https://jbasic.org/index.php/basicedu/index

\title{
Peran Kepemimpinan Efektif Dan Kedisiplinan Terhadap Komitmen Organisasi Dan Motivasi Maslow Pada Kinerja Tugas Guru di Sekolah Dasar
}

\author{
Aris Tri Haryanto ${ }^{1}$, Septiana Novita Dewi ${ }^{2}$ \\ STIE Adi Unggul Bhirawa Surakarta, Jawa Tengah, Indonesia ${ }^{1,2}$ \\ E-mail : arisharyanto26@yahoo.co.id ${ }^{1}$ septianadewi25@yahoo.co.id ${ }^{2}$
}

\begin{abstract}
Abstrak
Penelitian ini bertujuan untuk mengetahui dan menganalisis pengaruh kepemimpinan efektif dan kedisiplinan terhadap komitmen organisasi dan motivasi pada SD Negeri di Kota Surakarta. Mengetahui dan menganalisis pengaruh kepemimpinan efektif, kedisiplinan, komitmen organisasi dan motivasi guru terhadap kinerja tugas guru pada SD Negeri di Kota Surakarta. Populasi dalam penelitian ini adalah guru di SD Negeri di Kota Surakarta sejumlah 897 guru. Jumlah sampel dalam penelitian ini sebanyak 90 guru di SD Negeri di Kota Surakarta dan dengan tehnik random sampling. Hasil Uji Hipotesis Kepemimpinan efektif berpengaruh signifikan terhadap komitmen organisasi pada SD Negeri di Kota Surakarta. Kedisiplinan berpengaruh signifikan terhadap komitmen organisasi pada SD Negeri di Kota Surakarta. Kepemimpinan efektif berpengaruh signifikan terhadap motivasi pada SD Negeri di Kota Surakarta. Kedisiplinan berpengaruh signifikan terhadap motivasi pada SD Negeri di Kota Surakarta. Kepemimpinan efektif berpengaruh signifikan terhadap kinerja tugas guru pada SD Negeri di Kota Surakarta. Kedisiplinan berpengaruh signifikan terhadap kinerja tugas guru pada SD Negeri di Kota Surakarta. Komitmen organisasi berpengaruh tidak signifikan terhadap kinerja tugas guru pada SD Negeri di Kota Surakarta. Motivasi berpengaruh signifikan terhadap kinerja tugas guru pada SD Negeri di Kota Surakarta.

Kata kunci: kepemimpinan efektif, kedisiplinan, komitmen organisasi dan motivasi, kinerja tugas guru
\end{abstract}

\begin{abstract}
This study aims to determine and analyze the effect of effective leadership and discipline on organizational commitment to public elementary schools and on motivation in the city of Surakarta. Knowing and analyzing the effect of effective leadership, discipline, organizational commitment and teacher motivation on the performance of teacher assignments at the Public Elementary School in the City of Surakarta. The population in this study were 897 teachers at the Public Elementary School in Surakarta. The number of samples in this study were 90 teachers in public elementary schools in the city of Surakarta with random sampling technique. Hypothesis test results Effective leadership has a significant effect on organizational commitment in public elementary schools in the city of Surakarta. Discipline has a significant effect on organizational commitment to public elementary schools in the city of Surakarta. Effective leadership has a significant effect on motivation in public elementary schools in the city of Surakarta. Discipline has a significant effect on motivation in public elementary schools in Surakarta. Effective leadership has a significant effect on the performance of teacher assignments in public elementary schools in the city of Surakarta. Discipline has a significant effect on the performance of teacher assignments in public elementary schools in Surakarta. Organizational commitment has no significant effect on the performance of teacher assignments in public elementary schools in the city of Surakarta. Motivation has a significant effect on the performance of teacher assignments in public elementary schools in the city of Surakarta.

Keywords: effective leadership, discipline, organizational commitment and motivation, teacher task performance
\end{abstract}

Copyright (c) 2020 Aris Tri Haryanto, Septiana Novita Dewi

$\triangle$ Corresponding author:

Address : Perum Graha Sine Asri Sragen, Sumber Asri, Sine, Sragen

ISSN 2580-3735 (Media Cetak)

Email : arisharyanto26@yahoo.co.id

Phone :-

ISSN 2580-1147 (Media Online)

DOI: $10.31004 /$ basicedu.v4i4.448 


\section{PENDAHULUAN}

\begin{abstract}
Belajar merupakan suatu aktivitas yang dilakukan seseorang secara sadar untuk memperoleh perubahan perilaku secara positif dalam dirinya sebagai hasil dari pengalaman atau interaksi terhadap lingkungan sekitarnya. Perubahan-perubahan perilaku yang didapatkan dari proses belajar selalu berkesinambungan dan bersifat permanen. Proses belajar agar dapat berlangsung secara optimal tidak dapat terlepas dari keberadaan sumber belajar yang digunakan.
\end{abstract}

Sumber belajar adalah semua sarana maupun upaya yang digunakan untuk memperlancar jalannya proses belajar secara efektif, seperti media belajar, alat-alat peragaan, bahan-bahan belajar, pengajar, lingkungan, metode dan lain sebagainya.

Pengembangan kinerja lebih banyak merujuk pada konteks manajemen personalia, akhir-akhir ini makin meluas pada bidang lain seperti hukum, sosial, politik dan pemerintahan. Kualitas sumber daya manusia seringkali ditentukan oleh penilaian terhadap kinerjanya. Penilaian terhadap kinerja merupakan faktor penting untuk meningkatkan kinerja dan motivasi, bagian-bagian yang menunjukkan kemampuan guru yang kurang dapat diidentifikasi, diketahui sehingga dapat ditentukan strategi dalam meningkatkan kinerjanya. Kinerja dapat dipengaruhi oleh berapa faktor, diantaranya adalah kemampuan seorang guru atau kedisiplinan serta motivasi yang diterima guru akan menigkatkan kinerja tugas guru. Kinerja tugas guru masa kini lebih banyak dikaitkan dengan mutu pendidikan. Kinerja adalah hasil pekerjaan seorang pegawai dalam melaksanakan tugas yang dibebankan kepadanya. Kualitas kinerja tugas guru tampak dari perilaku yang mampu dan siap berperan secara profesional di sekolah dan masyarakat. Kinerja tugas guru seperti hal profesi yang lain dipengaruhi oleh banyak hal.

Membangun sistem pendidikan nasional secara bermutu adalah sebuah gairah dan pandangan hidup bagi kelembagaan pendidikan yang menerapkanya. Masalahnya adalah bagaimana membangkitkan keinginan dan hasrat untuk membangun sistem pendidikan nasional yang tentunya demi peningkatan mutu pendidikan itu sendiri. Petters dan Austin (Sallis, 2016) dalam bukunya A Passion for Excellence meyakinkan bahwa yang menentukan mutu dalam sebuah institusi adalah kepemimpinan efektif.

Dubrin (2015) menyatakan bahwa kepemimpinan efektif itu adalah upaya mempengaruhi banyak orang melalui komunikasi untuk mencapai tujuan, cara mempengaruhi orang dengan petunjuk atau perintah, tindakan yang menyebabkan orang lain bertindak atau merespon dan menimbulkan perubahan positif, kekuatan dinamis penting yang memotivasi guru dan mengkoordinasikan organisasi dalam rangka mencapai tujuan, kemampuan untuk menciptakan rasa percaya diri dan dukungan diantara bawahan agar tujuan organisasional dapat tercapai.

Kepemimpinan efektif merupakan kemampuan untuk mendorong sejumlah orang untuk bekerja sama guna melaksanakan kegiatankegiatan yang terarah pada tujuan organisasi. Peran kepemimpinan efektif yang sangat strategis dan penting bagi pencapaian visi misi dan tujuan 
SD Negeri di Kota Surakarta, merupakan salah satu alternatif yang mendorong guru untuk selalu menyelediki seluk-beluk yang terkait dengan kepemimpinan efektif. Kualitas dari pemimpin sering kali dianggap sebagai faktor terpenting dalam keberhasilan atau kegagalan organisasi, demikian juga keberhasilan atau kegagalan suatu organisasi baik yang berorientasi bisnis maupun publik, dipersepsikan sebagai keberhasilan atau kegagalan pemimpin. Begitu pentingnya peran pemimpin sehingga isu mengenai pemimpin menjadi fokus yang menarik perhatian para peneliti bidang perilaku keorganisasian.

Kepemimpinan efektif organisasi tentunya berhubungan dengan aspek perilaku kepemimpinan efektif organisasi dalam memperdayakan setiap guru untuk meningkatkan kualitas pembelajarannya, sehingga perlu adanya pemberian wewenang untuk meningkatkan kualitas pembelajarannya, memberikan kesempatan kepada setiap guru untuk dapat mengembangkan ketrampilan yang dimiliki dengan tujuan memberikan kualitas hasil kinerja yang optimal.

Dalam menegakkan kedisiplinan diperlukan peraturan dan hukuman, dengan tujuan untuk memberikan bimbingan bagi guru dalam menciptakan tata tertib yang baik didalam organisasi. Dengan tata tertib yang baik, semangat kerja, moral kerja, efisiensi dan efektifitas kerja guru akan meningkat. Organisasi akan sulit mencapai tujuannya jika guru tidak mematuhi peraturan yang berlaku. Untuk membangun kedisiplinan yang lebih efektif, dua dimensi penting harus diperhatikan yaitu organisasi dan perilaku. Dimensi ini sangat penting bagi program kedisiplinan dan terdiri dari kebijakan yang sering digunakan oleh pimpinan dalam membentuk program kedisiplinan.

Faktor yang mempengaruhi kinerja adalah komitmen organisasi. Komitmen organisasi merupakan keadaan dimana individu mempertimbangkan sejauhmana keinginannya untuk mempertahankan keanggotaanya dalam organisasi. Komitmen organisasi tingkah laku yang didasarkan pada sejauh mana guru menetapkan keputusan untuk terikat pada organisasi berkaitan dengan adanya kerugian jika memutuskan melakukan alternatif lain diluar pekerjaan. Berbeda dengan pendekatan sikap, pendekatan tingkah laku lebih menekankan pada proses dimana guru mengembangkan komitmen organisasi pada SD Negeri di Kota Surakarta. Kurangnya komitmen bagi guru SD Negeri di Kota Surakarta dapat dilihat dari tingkat tanggung jawab kerjanya terkadang masih mementingkan kepentingan pribadi, guru hanya menyelesaikan tugasnya masing-masing dan tidak ada kerja sama atau team work yang kuat untuk mewujudkan tujuan sekolah. Guru hanya berpikir bahwa pekerjaan bagi dirinya sudah selesai dan tidak berupaya untuk memberikan hasil yang lebih baik dan lebih optimal lagi.

Faktor yang tidak kalah penting dalam penelitian ini adalah motivasi, dalam penelitian ini menggunakan teori Maslow. Dalam teori Maslow banyak tingkah laku manusia yang bisa diterangkan dengan memperhatikan tendensi individu untuk mencapai tujuan-tujuannya dan membuat kehidupan lebih bermakna serta 
memuaskan. Dalam kenyataannya, proses-proses motivasional merupakan jantung dari teori Maslow.

Penjelasan mengenai konsep motivasi manusia menurut Abraham Maslow mengacu pada lima kebutuhan pokok yang disusun secara hirarkis. Tata lima tingkatan motivasi secara secara hierarkis ini adalah : 1) Kebutuhan yang bersifat fisiologis (lahiriyah), 2) Kebutuhan keamanan dan ke-selamatan kerja (Safety Needs), 3). Kebutuhan sosial (Social Needs), 4). Kebutuhan akan prestasi (Esteem Needs), 5). Kebutuhan mempertinggi kapisitas kerja (Self actualization).

Teori Motivasi menyatakan bahwa perilaku manusia dikendalikan oleh kedua faktor tersebut, yakni internal dan eksternal. Selain itu, Teori Maslow juga menyatakan bahwa manusia mempunyai kemampuan unik untuk membuat pilihan dan melaksanakan pilihan mereka sendiri. Penelitian yang dilakukannya membuat dirinya yakin bahwa orang memiliki kebutuhan tertentu yang tidak berubah dan asli secara genetis. Kebutuhan-kebutuhan ini sama dalam semua kebudayaan serta bersifat fisiologis dan psikologis. Maslow mengemukakan bahwa individu berperilaku dalam upaya untuk memenuhi kebutuhan yang bersifat hierarkis.

Menurut Hasibuan (2010) motivasi merupakan pemberian daya penggerak yang menciptakan semangat seseorang agar mau bekerja sama secara efektif dan berintegritas dengan segala kemampuan untuk mencapai kepuasan. Pemberian dorongan sebagai salah satu bentuk motivasi, penting dilakukan untuk meningkatkan semangat kerja guru di SD Negeri di Kota Surakarta sehingga dapat mencapai hasil yang dikehendaki. Dukungan motivasi guru, semangat kerja dan hasil yang optimal mempunyai bentuk yang linear atau dengan kata lain pemberian motivasi kerja yang baik, maka semangat kerja guru akan meningkat dan hasil kerja akan menjadi optimal sesuai standar kerja yang ditetapkan. Setiap guru di SD Negeri di Kota Surakarta memerlukan motivasi yang kuat agar bersedia melaksanakan pekerjaannya secara bersemangat, bergairah dan berdedikasi yang selama ini belum optimal, misalkan apabila ada beban kerja yang berlebih tidak ada tambahan atau insentif yang diberikan, selain itu kurangnya penghargaan atas prestasi yang dihasilkan membuat guru menjadi tidak termotivasi untuk bekerja secara maksimal.

Determinan yang penting bagi prestasi individu adalah motivasi, motivasi dapat mempengaruhi perilaku dan prestasi individu. Dalam proses pembelajaran di sekolah, guru sering kali menghadapi masalah mengenai perilaku siswa, ada siswa yang prestasinya baik dan sebaliknya, ada siswa yang belajar penuh semangat dan sebaliknya ada yang belajar seadanya. Motivasi merupakan suatu kekuatan yang mendorong seseorang untuk melakukan suatu kegiatan. Sedangkan motif yang bersifat potensial dan aktualisasinya dinamakan motivasi. Pada umumnya diwujudkan dalam bentuk perbuatan nyata. Motivasi dapat mempengaruhi prestasi seseorang dalam melakukan kegiatan tertentu. Apabila siswa mempunyai motivasi belajar yang tinggi, mereka akan terdorong dan berusaha untuk meningkatkan kemampuannya dalam meningkatkan prestasi belajar. Keberhasilan 
sekolah dalam meningkatkan prestasi belajar siswa tidaklah dicapai dengan cara yang mudah. Hal tersebut hanya dapat terjadi berkat kepiawaian pihak sekolah dalam memahami kebutuhan siswa dan kepuasan siswa, selain kemampuan sekolah dalam menciptakan lingkungan belajar yang kondusif sehingga para siswa merasa termotivasi secara internal.

Untuk memahami kebutuhan siswa dan kepuasan siswa salah satunya dengan konsep motivasi. Motivasi adalah suatu konsep yang menguraikan kekuatan-kekuatan yang ada dalam diri individu yang memulai dan mengarahkan perilaku. Konsep motivasi digunakan untuk menjelaskan perbedaan-perbedaan dalam intensitas perilaku, di mana perilaku yang lebih bersemangat adalah hasil dari tingkat motivasi yang lebih kuat. Selain itu konsep motivasi juga digunakan untuk menunjukkan arah perilaku. Untuk memotivasi individu, perlu diketahui seberapa besar tingkat kebutuhan individu. Kebutuhan merupakan kekurangan yang dirasakan seseorang pada suatu waktu tertentu. Kekurangan tersebut dapat bersifat fisiologis, psikologis, maupun sosiologis. Perbedaan kebutuhan individu dalam kelompok harus dipertimbangkan oleh sekolah dalam upaya memotivasi siswa dalam proses pembelajaran. Berdasarkan uraian tersebut di atas, maka penulis tertarik untuk mengkaji lebih mendalam pada penelitian yang berjudul "Peran Kepemimpinan Efektif Dan Kedisiplinan Terhadap Komitmen Organisasi Dan Motivasi Menurut Maslow Yang Berdampak Pada Kinerja Tugas Guru SD Negeri Di Kota Surakarta”.

\section{METODE}

Populasi dalam penelitian ini adalah guru di SD Negeri di Kota Surakarta sejumlah 897 guru. Peneliti mengambil sampel sebesar 10\% yaitu $897 \times 10 \%=89,7$, dibulatkan menjadi 90 agar mendapatkan hasil yang lebih baik, sehingga jumlah sampel dalam penelitian ini sebanyak 90 guru di SD Negeri di Kota Surakarta. Dengan tehnik random sampling, yaitu teknik pengambilan secara acak. Teknik analisis yang digunakan adalah analisis jalur (Path Analysis).

\section{HASIL DAN PEMBAHASAN}

\section{Hasil Uji Instrument}

Hasil pengujian validitas menggunakan teknik one shot methods yaitu dengan membandingkan nilai $\mathrm{r}_{\text {hitung }}$ dengan nilai $\mathrm{r}_{\text {tabel }}=$ 0,205 dan didapatkan hasil dari seluruh item pertanyaan semua valid karena mempunyai nilai $r_{\text {item }}$ lebih besar dari nilai $r_{\text {tabel }}$

Tabel 1. Hasil Uji Reliabilitas

\begin{tabular}{lcl}
\hline \multicolumn{1}{c}{ Variabel } & $\begin{array}{c}\text { Alpha } \\
\text { Cronbach }\end{array}$ & Keterangan \\
\hline Kepemimpinan & 0,916 & Reliabel \\
efektif & 0,889 & Reliabel \\
Kedisiplinan & 0,875 & Reliabel \\
komitmen organisasi & 0,919 & Reliabel \\
Motivasi & 0,905 & Reliabel \\
Kinerja & & \\
\hline Sumber : Data yang diolah, 2020 &
\end{tabular}

\section{Hasil Analisis Jalur (Path Analysis)}

Hasil Analisis Jalur Persamaan 1 


\section{Tabel 2. Hasil Analisis Jalur Persamaan 1}

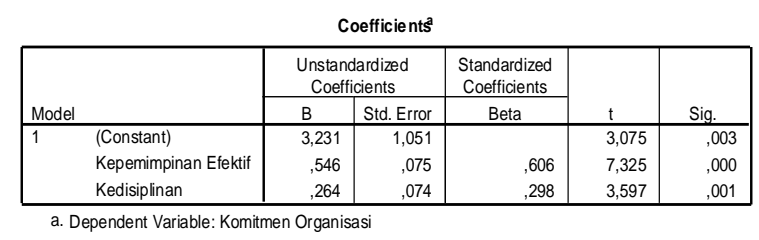

Sumber : Data yang diolah, 2020

Hasil persamaan regresi dapat dijelaskan sebagai berikut:

$\mathrm{Y}_{1}=0,606 \mathrm{X}_{1}+0,298 \mathrm{X}_{2}+\epsilon$

Keterangan:

1. $\beta_{1}=$ nilai koefisien regresi kepemimpinan efektif sebesar 0,606, hal ini menunjukkan bahwa kepemimpinan efektif berpengaruh positif terhadap komitmen organisasi Guru di SD Negeri di Kota Surakarta.

2. $\beta_{2}=$ koefisien regresi kedisiplinan sebesar 0,298, hal ini menunjukkan bahwa kedisiplinan berpengaruh positif terhadap komitmen organisasi Guru di SD Negeri di Kota Surakarta.

Hasil Analisis Jalur Persamaan 2

Tabel 3. Hasil Analisis Jalur Persamaan 2

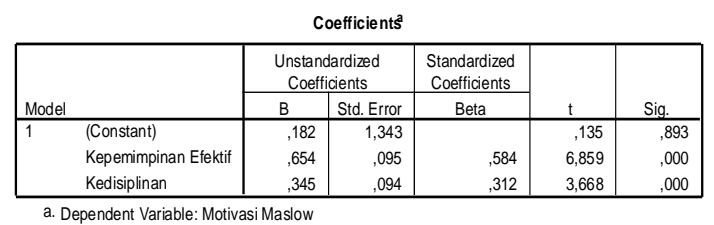

Sumber : Data yang diolah, 2020

Hasil persamaan regresi kedua dapat dijelaskan sebagai berikut:

$Y_{2}=0,584 X_{1}+0,312 X_{2}+\epsilon$

Keterangan:
1. $\beta_{1}=$ koefisien regresi kepemimpinan efektif sebesar 0,584, hal ini menunjukkan bahwa kepemimpinan efektif berpengaruh positif terhadap motivasi Guru di SD Negeri di Kota Surakarta.

2. $\beta_{2}=$ koefisien regresi kedisiplinan sebesar 0,312 , hal ini menunjukkan bahwa kedisiplinan berpengaruh positif terhadap motivasi Guru di SD Negeri di Kota Surakarta.

Hasil Analisis Jalur Persamaan 3

Tabel 4. Hasil Analisis Jalur Persamaan 3

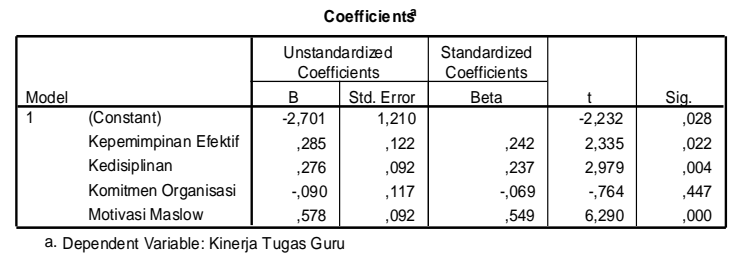

Sumber : Data yang diolah, 2020

Hasil persamaan regresi ketiga dapat dijelaskan sebagai berikut:

$Y_{3}=0,242 X_{1}+0,237 X_{2}-0,069 X_{3}+0,549 X_{4}+$ $\epsilon$

Keterangan:

1. $\beta_{1}=$ koefisien regresi kepemimpinan efektif sebesar 0,242, hal ini menunjukkan bahwa kepemimpinan efektif berpengaruh positif terhadap kinerja tugas guru di SD Negeri di Kota Surakarta.

2. $\beta_{2}=$ koefisien regresi kedisiplinan sebesar 0,237, hal ini menunjukkan bahwa kedisiplinan berpengaruh positif terhadap kinerja tugas guru di SD Negeri di Kota Surakarta.

3. $\beta_{3}=$ koefisien regresi komitmen organisasi sebesar -0,069, hal ini menunjukkan bahwa 
variabel komitmen organisasi berpengaruh negatif terhadap kinerja tugas guru di SD Negeri di Kota Surakarta.

4. $\beta_{4}=$ koefisien regresi motivasi sebesar 0,549 , hal ini menunjukkan bahwa motivasi berpengaruh positif terhadap kinerja tugas guru di SD Negeri di Kota Surakarta.

\section{Hasil Uji Hipotesis}

Hasil uji hipotesis dalam penelitian ini diantaranya adalah sebagai berikut:

1. Hasil Uji t variabel kepemimpinan efektif berpengaruh signifikan terhadap komitmen organisasi. Hal ini dapat dilihat dari nilai signifikansi yaitu $0,000<0,05$. (Hipotesis 1 terbukti).

2. Hasil Uji t variabel kedisiplinan berpengaruh signifikan terhadap komitmen organisasi. Hal ini dapat dilihat dari nilai signifikan yaitu 0,001 $<0,05$. (Hipotesis 2 terbukti).

3. Hasil Uji t variabel kepemimpinan efektif berpengaruh signifikan terhadap motivasi Guru di SD Negeri di Kota Surakarta, hal ini dapat dilihat dari nilai signifikan yaitu $0,000<0,05$. (Hipotesis 3 terbukti).

4. Hasil Uji t variabel kedisiplinan berpengaruh signifikan terhadap motivasi Guru di SD Negeri di Kota Surakarta, hal ini dapat dilihat dari nilai signifikansi yaitu $0,000<0,05$. (Hipotesis 4 terbukti).

5. Hasil uji $t$ variabel kepemimpinan efektif berpengaruh signifikan terhadap kinerja tugas guru di SD Negeri di Kota Surakarta, hal ini dapat dilihat dari nilai signifikansi yaitu 0,022 $<0,05$. (Hipotesis 5 terbukti).
6. Hasil uji $\mathrm{t}$ variabel kedisiplinan berpengaruh signifikan terhadap kinerja tugas guru di SD Negeri di Kota Surakarta, hal ini dapat dilihat dari nilai signifikansi yaitu $0,004<0,05$. (Hipotesis 6 terbukti).

7. Hasil uji $\mathrm{t}$ variabel komitmen organisasi berpengaruh tidak signifikan terhadap kinerja tugas guru di SD Negeri di Kota Surakarta, hal ini dapat dilihat dari nilai signifikansi yaitu $0,447>0,05$. (Hipotesis 7 tidak terbukti).

8. Hasil uji $\mathrm{t}$ variabel motivasi berpengaruh signifikan terhadap kinerja tugas guru di SD Negeri di Kota Surakarta, hal ini dapat dilihat dari nilai signifikansi yaitu $0,000<0,05$. (Hipotesis 8 terbukti).

\section{Hasil Uji F}

Tabel 5. Hasil Uji F

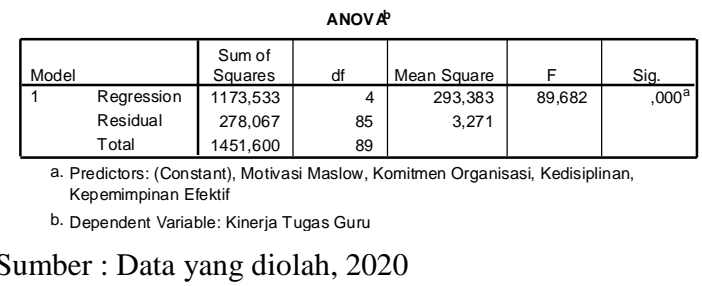

Hasil uji $\mathrm{F}$ diketahui besarnya nilai $\mathrm{F}$ $=89,682$ signifikansi $0,000<0,05$, sehingga dapat disimpulkan secara bersama-sama variabel kepemimpinan efektif, kedisiplinan, komitmen 
Tabel 6. Hasil Perhitungan Langsung dan Tidak Langsung

\begin{tabular}{|c|c|c|c|c|c|}
\hline \multirow{2}{*}{ Dari Variabel } & \multicolumn{2}{|c|}{ Koefisien Jalur } & \multirow{2}{*}{ Total Pengaruh } & \multirow{2}{*}{$t$-test } & \multirow{2}{*}{$p$-value } \\
\hline & Langsung & Tidak Langsung & & & \\
\hline $\begin{array}{l}\text { Kepemimpinan efektif } \rightarrow \\
\text { kinerja }\end{array}$ & $\mathrm{P}_{5}=0,242$ & & & & \\
\hline Kedisiplinan $\rightarrow$ kinerja & $P_{6}=0,237$ & & & & \\
\hline $\begin{array}{l}\text { Kepemimpinan efektif } \rightarrow \\
\text { komitmen organisasi } \rightarrow \\
\text { kinerja }\end{array}$ & & $\begin{array}{l}P_{1} \times P_{7}= \\
0,606 \times(-0,069) \\
=-0,042\end{array}$ & $\begin{array}{l}P_{5}+\left(P_{1} \times P_{7}\right)= \\
0,242+(-0,042) \\
=0,2\end{array}$ & -0.588 & 0.556 \\
\hline $\begin{array}{ll}\text { Kedisiplinan } & \rightarrow \\
\text { komitmen organisasi } & \rightarrow \\
\text { kinerja } & \end{array}$ & & $\begin{array}{l}P_{2} \times P_{7}= \\
0,298 \times(-0,069) \\
=-0,020\end{array}$ & $\begin{array}{l}\mathrm{P}_{6}+\left(\mathrm{P}_{2} \times \mathrm{P}_{7}\right)= \\
0,237+(-0,020) \\
=0,217\end{array}$ & -0.583 & 0.559 \\
\hline $\begin{array}{l}\text { Kepemimpinan efektif } \rightarrow \\
\text { motivasi } \rightarrow \text { kinerja }\end{array}$ & & $\begin{array}{l}\mathrm{P}_{3} \times \mathrm{P}_{8}= \\
0,584 \times 0,549 \\
=\mathbf{0 , 3 2 0}\end{array}$ & $\begin{array}{l}P_{5}+\left(P_{3} \times P_{8}\right)= \\
0,242+0,320 \\
=0,562\end{array}$ & 4.281 & 0.000 \\
\hline $\begin{array}{l}\text { Kedisiplinan } \rightarrow \text { motivasi } \\
\rightarrow \text { kinerja }\end{array}$ & & $\begin{array}{l}\mathrm{P}_{4} \times \mathrm{P}_{8}= \\
0,312 \times 0,549 \\
=0,171\end{array}$ & $\begin{array}{l}P_{6}+\left(P_{4} \times P_{8}\right)= \\
0,237+0,171 \\
=0,408\end{array}$ & 2.900 & 0.003 \\
\hline
\end{tabular}

Sumber : Data yang diolah, 2020

organisasi dan motivasi mempengaruhi kinerja tugas guru di SD Negeri di Kota Surakarta.

\section{Hasil Uji Koefisien Determinasi}

Nilai $\mathrm{R}^{2}$ total sebesar 0,984 dapat diartikan variasi kinerja tugas guru di SD Negeri di Kota Surakarta dijelaskan oleh variabel kepemimpinan efektif, kedisiplinan, komitmen organisasi dan

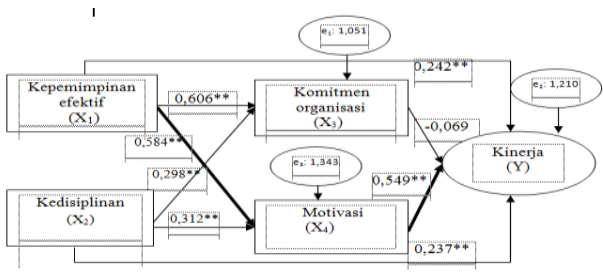

Gambar 1. Pengaruh Langsung dan Tidak Langsung

Sumber : Data yang diolah, 2020 motivasi sebesar $98,4 \%$ dan sisanya $1,6 \%$ dijelaskan variabel lain diluar model penelitian sebagai contoh stres kerja, pelatihan dan lain sebagainya.

\section{Hasil Perhitungan Pengaruh Langsung dan Tidak Langsung}

Berdasarkan Tabel. 6 di atas hubungan antar variabel dapat digambarkan sebagai berikut:

1. Pengaruh kepemimpinan efektif terhadap kinerja melalui komitmen organisasi

Pengaruh tidak langsung kepemimpinan efektif terhadap kinerja melalui komitmen organisasi adalah tidak efektif, karena pengaruh tidak langsung lebih kecil hasilnya dibandingkan pengaruh langsung. Langkah kongkrit yang perlu ditingkatkan merupakan indikator variabel kepemimpinan efektif 
adalah: Pimpinan mempunyai ketrampilan berkomunikasi dengan baik, Pimpinan selalu bertindak jujur dalam segala pekerjaan, Pimpinan mempunyai kemampuan mengajar yang baik saat menjelaskan pekerjaan.

2. Pengaruh kedisiplinan terhadap kinerja melalui komiten organisasi

Pengaruh tidak langsung kedisiplinan terhadap kinerja melalui komitmen organisasi adalah tidak efektif, karena pengaruh tidak langsung lebih kecil hasilnya dibandingkan pengaruh langsung. Langkah kongkrit yang perlu ditingkatkan merupakan indikator variabel kedisiplinan adalah: Pimpinan selalu memberikan teladan yang baik dalam menyelesaikan pekerjaan. Guru yang tidak disiplin akan mendapatkan sanksi hukum yang sudah ditetapkan. Pemimpin selalu bersikap tegas dalam menjelaskan tugastugas.

3. Pengaruh kepemimpinan efektif terhadap kinerja melalui motivasi

Pengaruh tidak langsung kepemimpinan efektif terhadap kinerja melalui motivasi adalah efektif, karena pengaruh tidak langsung lebih besar hasilnya dibandingkan pengaruh langsung. Langkah kongkrit yang perlu ditingkatkan merupakan indikator variabel motivasi adalah: Guru dapat bekerja dengan antusias dan penuh produktivitas bila dirasakan adanya jaminan formal atas kedudukan dan wewenangnya. Guru membutuhkan promosi yang adil dalam mengoptimalkan kinerjanya. Rasa kebersamaan termasuk adanya sense of belonging (rasa memiliki) dalam organisasi.

4. Pengaruh kedisiplinan terhadap kinerja melalui motivasi

Pengaruh tidak langsung kedisiplinan terhadap kinerja melalui motivasi adalah tidak efektif, karena pengaruh tidak langsung lebih kecil hasilnya dibandingkan pengaruh langsung. Langkah kongkrit yang perlu ditingkatkan merupakan indikator variabel kedisiplinan adalah: Pimpinan selalu memberikan teladan yang baik dalam menyelesaikan pekerjaan. Guru yang tidak disiplin akan mendapatkan sangsi hukum yang sudah ditetapkan. Pemimpin selalu bersikap tegas dalam menjelaskan tugastugas.

\section{KESIMPULAN}

1. Hasil pengujian hipotesis adalah sebagai berikut:

a. Kepemimpinan efektif berpengaruh signifikan terhadap komitmen organisasi pada SD Negeri di Kota Surakarta.

b. Kedisiplinan berpengaruh signifikan terhadap komitmen organisasi pada SD Negeri di Kota Surakarta

c. Kepemimpinan efektif berpengaruh signifikan terhadap motivasi pada SD Negeri di Kota Surakarta

d. Kedisiplinan berpengaruh signifikan terhadap motivasi pada SD Negeri di Kota Surakarta. 
810 Peran Kepemimpinan Efektif Dan Kedisiplinan Terhadap Komitmen Organisasi Dan Motivasi Maslow Pada Kinerja Tugas Guru di Sekolah Dasar - Aris Tri Haryanto, Septiana Novita Dewi

DOI: 10.31004/basicedu.v4i4.448

e. Kepemimpinan efektif berpengaruh signifikan terhadap kinerja tugas guru pada SD Negeri di Kota Surakarta.

f. Kedisiplinan berpengaruh signifikan terhadap kinerja tugas guru pada SD Negeri di Kota Surakarta.

g. Komitmen organisasi berpengaruh tidak signifikan terhadap kinerja tugas guru pada SD Negeri di Kota Surakarta.

h. Motivasi berpengaruh signifikan terhadap kinerja tugas guru pada SD Negeri di Kota Surakarta.

2. Hasil Analisis Jalur:

a. Pengaruh kepemimpinan efektif dan kedisiplinan terhadap kinerja melalui komitmen organisasi lebih besar dari pengaruh langsung sehingga jalur ini efektif.

b. Pengaruh kepemimpinan efektif terhadap kinerja melalui motivasi lebih besar sehingga jalur ini efektif.

c. Pengaruh kedisiplinan terhadap kinerja melalui motivasi lebih kecil sehingga jalur ini tidak efektif.

3. Kepemimpinan melalui motivasi merupakan variabel yang paling dominan dalam mempengaruhi kinerja tugas guru di SD Negeri di Kota Surakarta

Saran yang dapat diberikan yakni

1. Dalam rangka meningkatkan kinerja tugas guru di SD Negeri di Kota Surakarta lebih baik melalui peningkatan motivasi dan kepemimpinan efektif karena merupakan variabel mediasi paling dominan dalam mempengaruhi kinerja tugas guru. Hal yang dapat dilakukan dalam meningkatkan motivasi antara lain : Guru dapat bekerja dengan antusias dan penuh produktivitas bila dirasakan adanya jaminan formal atas kedudukan dan wewenangnya. Guru membutuhkan promosi yang adil dalam mengoptimalkan kinerjanya. Rasa kebersamaan termasuk adanya sense of belonging (rasa memiliki) dalam organisasi. Hal yang dapat dilakukan dalam meningkatkan kepemimpinan efektif antara lain : Pimpinan selalu menjaga stabilitas emosi saat bekerja. Pimpinan selalu bertindak jujur dalam segala pekerjaan. Pimpinan selalu bersikap obyektif terhadap semua guru

2. Bagi peneliti yang akan datang hendaknya dapat mengimplementasikan model penelitian pada tempat yang berbeda atau menambah variabel yang ada dalam penelitian selanjutnya.

3. Variabel komitmen organisasi sebaiknya tetap digunakan sebagai variabel independen.

\section{DAFTAR PUSTAKA}

Dwi Agung Nugroho Arianto (2013). Pengaruh Kedisiplinan, Lingkungan Kerja Dan Budaya Kerja Terhadap Kinerja tugas Tenaga Pengajar. Jurnal Economia, Volume 9, Nomor 2, Oktober 2013

Dyer, Lee, dan Donald F Parker, (2010), Classfying Outcomes in Work Motivating Research: An Examination of The Intrinsic dan Extrinsic Dichotomy, "Journal of Applied Psichology, 455-458.

Edi, (2010). Pengaruh Kompetensi kerja Terhadap Motivasi Dan Kepuasan kerja intrinsik Serta 
Kinerja tugas Guru Pada Sub Sektor Industri Pengolahan Kayu Skala Menengah Di Jawa Timur. Jurnal Manajemen \& Kewirausahaan, VOL. 7, NO. 2, September 2005: 171-188

Haryanto A.T, Septiana N.D, Siti F, (2020). Kepuasan Kerja Intrinsik Memediasi Pengaruh Kompetensi Kerja dan Lingkungan Kerja Pada Kinerja di Sekolah Dasar. Jurnal Basicedu pages: 754-764 Vol.4 No.3 (2020)P-ISSN 2580-3735 e-ISSN 2580-1147.

DOI: https://doi.org/10.31004/basicedu.v4i3 .426

Haryadi Sarjono, Lim Sanny, Sheftian Pancha Cahyo (2013). Review of Organizational Culture, Style Leadership Affect Job Satisfaction on Employee Performance at PT. Motor Nasional. Jakarta Based Approach SPSS vs LISREL Global Network Journal, Vol. 5 No. 1 March 2012 p.36-57

Hendrawan, 2012, Pengaruh pendidikan pelatihan, kepuasan kerja dan komunikasi terhadap kinerja melalui budaya organisasi di Pemkab Semarang, Bisnis dan Manajemen Unisbank Semarang. Vol 23. No.3 hal. 4565

Ideswal,Yahya dan Hanif Alkadri. (2020). Kontribusi Iklim Sekolah Dan Kepemimpinan Kepala Sekolah Terhadap Kinerja tugas guru Sekolah Dasar. Jurnal Basicedu Vol 4 No 2 April 2020 p-ISSN 2580-3735 e-ISSN 2580-1147 DOI: 10.31004/basicedu.v4i2.381

I Wayan Mudiartha Utama (2012). Pengaruh Motivasi, Lingkungan Kerja, Kompetensi Dan Kompensasi Terhadap Kepuasan kerja intrinsik Dan Kinerja tugas Di Lingkungan Kantor Dinas Pekerjaan Umum Provinsi Bali Anak Agung Ngurah Bagus Dhermawan, I Gde Adnyana Sudibya. Jurnal Manajemen, Strategi Bisnis, dan Kewirausahaan Vol. 6, No. 2 Agustus 2012

Leonard, Robert W. College (2012). The impact of corpora organizing and leader Behavior on satisfaction in nonprofits. Journal of
Occupational and Organizational Psychology. Proceedings of ASBBS. Vol.19. No.1

Linawati Dan Suhaji (2014). Pengaruh Motivasi, Kompetensi, Kepemimpinan, Dan Lingkungan Kerja Terhadap Kinerja tugas Guru (Studi Pada PT. Herculon Carpet Semarang). http//jurnal.widyamanggala.ac.id/index.php/ wmkeb/article/ 2014. Sekolah Tinggi Ilmu Ekonomi Widya Manggala.

Luthans F., 2012, Organizational Behavioural, 7th Edition, McGraw-Hill, New York. Macy B. A., M. F. Peterson, \& L. W. Norton, 1989, "A Test of Participation Theory in a Work Redesign Field Setting: Degree of Participation and Comparation Site Contracts", Human Relation, 42(12): 10951165 .

Mangkunegara, Anwar Prabu. 2014. Manajemen Sumber Daya Manusia. Bandung: Remaja Rosda Karya.

Moenir, 2014. Metodologi Penelitian, Aplikasi dalam Pemasaran, Jakarta : Penerbit PT Gramedia Pustaka Utama

Nitisemito, Alex. 2010, Management Personalia (Manajemen Sumber Daya Manusia), sasamito Bros, Bandung.

Ostroff, 2013. Relationship between Satisfaction, attitude and performance an organization level analisis". Journal of Applied Psycology, Vol:77, No.6, p.933-973

Reza Amelia (2013). Pengaruh Kompetensi kerja Dan Stres Kerja Terhadap Kinerja tugas Melalui Kepuasan kerja intrinsik Sebagai Variabel Intervening ( Studi Pada Bank Mandiri Cabang Padang). http://journal.fekon.unand.ac.id/Jurnal FE Universitas Andalas Vol. 1 (2013) No. 1

Sartika (2010). Analisis Pengaruh disiplin kerja, Kompetensi kerja Terhadap Kinerja tugas Guru Dengan Kepuasan kerja intrinsik Sebagai Variabel Intervening (Studi pada PT. Coca Cola Amatil Indonesia (Central 
Java). Jurnal Bisnis \& Manajemen, Vol 3. No. 2 p.81-93

Sarwono, Jonathan. 2010. Analisis Jalur Untuk Bisnis dengan SPSS. Penerbit Andi Offset:Yogyakarta.

Schein E., 2014, Organizational Culture and Leadership, San Frasisco Jossey Bass.

Sedarmayanti. 2012. Tata Kerja dan Produktivitas Kerja Suatu Tinjauan dari Aspek Ergonomi atau Kaitan antara Manusia dengan Lingkungan Kerja, Bandung : Mandar Maju.

Simamora, Henry. 2014. Manajemen Sumber Daya Manusia. Edisi kedua Sekolah Tinggi Ilmu Ekonomi (YKPN). Yogyakarta.

Siswanto, 2013,Riset Sumber Daya Manusia, Jakarta:PT. Gramedia Pustaka Utama.

Stephanie Tanto Kurniawan, Faustine (2014). Pengaruh Komunikasi Dan Kepuasan kerja intrinsik Guru Terhadap Kinerja tugas Guru Departemen Front Office Hotel "X" Surabaya. Jurnal Hospitality dan Manajemen Jasa Vol. 1 Tahun 2015. http://studentjournal.petra.ac.id

Stoner, James A.F, 2011. Management, Third Edition. Prentice-Hall International Inc.Englewood.Chlips.New Jersey

Syufriati dan Gustina, (2020). Peningkatan Kompetensi Pedagogik Guru Dalam Membuat Perencanaan Pembelajaran Melalui Supervisi Akademik. Jurnal Basicedu Vol 4 No 2 April 2020 p-ISSN 2580-3735 e-ISSN 2580-1147 DOI: 10.31004/basicedu.v4i2.360

Yafang Tsai, (2011). Relationship between Organizational Culture, Leadership Behavior and Job Satisfaction. Tsai BMC Health Services Research 2011, 11:98 